\title{
MANIFESTO DE ENTIDADES NACIONAIS DE EDUCAÇÃO SOBRE O GOVERNO PROVISÓRIO (AbdC/ANFOPE/ANPAE/ANPEd/CEDES/FÓRUMDIR)
}

Um governo provisório não pode comprometer negativamente o futuro.

As entidades que subscrevem este manifesto compreendem que a aprovação da admissibilidade do impeachment da presidente Dilma Rousseff expressa uma ruptura institucional promovida por coalisão de forças políticas derrotadas nas urnas nas últimas eleições presidenciais e por agentes econômicos que buscam consolidar o conservadorismo e aprofundar desigualdades em nosso país. Temos a firme convicção de que o Governo provisório do Vice-Presidente Michel Temer, que não tem legitimidade nem aceitação da população brasileira, iniciou de forma irresponsável suas decisões relativas às pastas daEducação, da Cultura e da Ciência e Tecnologia. O afastamento da Presidente eleita Dilma Rousseff por 180 dias e a posse do vice presidente para um mandato como presidente em exercício por este período não pode significar descontinuidade na construção e manutenção da política educacional construída de forma negociada com a sociedade organizada. Um governo provisório não pode comprometer um projeto de educação construído em duas Conferências Nacionais de Educação, discutido, negociado e expresso no Plano Nacional de Educação aprovado em 2014.0 documento do PMDB "Uma ponte para o futuro" e as primeiras horas de atuação do novo Ministro da Educação já foram indícios suficientes para que se pudesse perceber que encontra-se em curso uma política de terra arrasada visando destruir as políticas implementadas do "governo derrotado" pela admissibilidade do impeachmeant. Em especial, a noção de "Orçamento com base zero" para as políticas e programas sociais representa um duro golpe naquilo que se já se avançou no Estado brasileiro para a construção da necessária segurança orçamentária para a continuidade republicana das políticas públicas. O PNE tem duas orientações muito explicitamente construídas para a garantia do direito à educação no Brasil: 1) a meta 20, que determina a ampliação de recursos para educação tendo como referência o crescimento dos investimentos em relação ao PIB brasileiro. Esta meta não admite qualquer possibilidade de desvinculação de recursos para educação; 2) a necessidade de assegurar uma educação pública, gratuita, de qualidade, inclusiva e que respeite a diversidade. Assim, é imprescindível que o projeto educacional brasileiro assegure as condições de construção e consolidação do Sistema Nacional de Educação, respeitando o diálogo democrático com o conjunto plural de sujeitos que compõe este sistema. Expressamos nossa preocupação com as medidas recentes do presidente em exercício que colocam em risco conquistas importante para um projeto de inclusão e construção de cidadania efetiva no Brasil. Outro ponto crítico 
refere-se ao equívoco de fusão do Ministério da Educação com o Ministério da Cultura, que além de evidenciar a não disposição para o diálogo com a sociedade civil organizada e especialistas do setor, coloca em risco as condições de garantia de políticas públicas nas duas áreas. O mesmo se coloca com a fusão do Ministério da Ciência Tecnologia e Inovação com o Ministério das Comunicações. A preocupação é que mudanças demagógicas em nome de uma equivocada diminuição de custos na administração pública coloquem em risco políticas estruturantes. A descontinuidade destas significará retrocessos nas condições de produção científica, formação humana e desenvolvimento social do país. Esperamos e cobraremos dos dirigentes que assumem interinamente a gestão da politica educação, científica e cultural do país responsabilidade republicana para a travessia do grave momento vivido pela democracia no Brasil.

Anped - Associação Nacional de pós graduação e pesquisa em EDUCAÇÃO

Anpae- ASSOCIAÇÃO NACIONAL DE POLÍTICA E ADMINISTRAÇÃO ESCOLAR

Anfope - ASSOCIAÇÃO NACIONAL PELA FORMAÇÃO DOS PROFISSIONAIS DA EDUCAÇÃO

Cedes - CENTRO DE ESTUDOS EDUCAÇÃO E SOCIEDADE

Forumdir- FÓRUM DE DIRETORES DAS FACULDADES DE EDUCAÇÃO

AbdC - Associação Brasileira de Currículo 